\title{
Growth parameters and meat quality of Pekin ducks fed on different level of dried distillers grains with solubles
}

\author{
Ewa Łukaszewicz' , Artur Kowalczyk ${ }^{1}$, Marek Adamski1,2 and Joanna Kuźniacka² \\ 'Department of Poultry Breeding, Institute of Animal Breeding, Wroclaw University of Environmental and Life \\ Sciences, Wroclaw, Poland, ${ }^{2}$ Department of Poultry Breeding, University of Technology and Life Sciences in Bydgoszcz, \\ Bydgoszcz, Poland
}

\begin{abstract}
The experiment was carried out on 160 commercial Pekin ducks, strain P55. At the day of hatching birds were sexed, marked individually, weighed and divided randomly into four equal groups (four sup-groups, each). From Day 1 to Day 21 all birds received the same commercial feed, while from 4th to 8th week of rearing were fed in the following feeding groups: control, fed with commercial feed and experimental: with $15 \%, 25 \%$ and $30 \%$ inclusion of dried distillers grains with solubles (DDGS). At 8th week of rearing from every group five males and five females were selected semi-randomly, slaughtered conventionally and slaughter yield, carcass composition and physicochemical meat characteristics were evaluated. Results from this study showed that Pekin ducks can be fed on diets containing up to $25 \%$ DDGS without any significant decrease in slaughter yield, muscles contents and breast meat quality. Higher DDGS level $(30 \%)$ caused significant $(P<0.05)$ decrease in final body weight and slaughter yield of females, however, the percentage of skin with subcutaneous fat and abdominal fat contents were lower $(P<0.05)$.
\end{abstract}

Keywords: Pekin ducks, DDGS, slaughter efficiency, meat quality

\section{Zusammenfassung}

\section{Wachstumsparameter und Fleischqualität von Pekingenten, die mit unterschiedlichen Anteilen von Trockenschlempe gefüttert wurden}

Das Experiment wurde mit 160 Pekingenten, Stamm P55 durchgeführt. Am Schlupftag wurden die Tiere gesext, markiert, einzeln gewogen und nach dem Zufallsprinzip in vier gleich große Gruppen unterteilt. Von Tag 1 bis Tag 21 erhielten alle Tiere das gleiche handelsübliche Futter, während von der 4. bis zur 8. Woche der Aufzucht folgende Fütterungsgruppen eingerichtet wurden: Kontrollgruppe, handelsübliches Futter und Versuchsfütterung mit 15\%, 25\% und 30\% Anteil Trockenschlempe (DDGS). In der 8. Aufzuchtswoche wurden aus jeder Gruppe fünf männliche und fünf weibliche Tiere ausgewählt und konventionell geschlachtet. Ausgewertet wurden Schlachtertrag, Schlachtkörperzusammensetzung und physikalisch-chemische Fleischeigenschaften. Die Ergebnisse dieser Studie zeigten, dass dem Futter von Pekingenten bis zu 25\% DDGS zugefügt werden kann ohne signifikante Minderung des Schlachtertrags, der Muskelmasse und der Brustfleischqualität. Höhere DDGS-Anteile $(30 \%)$ verursachten signifikant $(P<0,05)$ eine Veringerung des Körpergewichts 
und des Schlachtertrags bei weiblichen Tieren, allerdings war der prozentuale Anteil von Unterhautfett und Bauchfett niedriger $(\mathrm{P}<0,05)$.

Schlüsselwörter: Pekingenten, DDGS, Schlachteffizienz, Fleischqualität

\section{Introduction}

Rapid increase in bioethanol production results in growing quantities of byproducts that can be used as animal feed component. Dried distillers grain with solubles (DDGS) is one of the most popular by-products from ethanol refineries and due to its high level of starch and low content of no starch polysaccharides is particularly valuable in poultry feeding (Świątkiewicz \& Koreleski 2008). There are many publications indicating DDGS as valuable and satisfactory component of chicken broilers (Lumpkins et al. 2004, Wang et al. 2007, Corzo et al. 2009), turkeys (Roberson 2003) and laying hens diet (Lumpkins et al. 2005, Roberson et al. 2005, Świątkiewicz \& Koreleski 2006), but there are no publication carried on ducks. Świątkiewicz \& Koreleski (2003) stated that $10 \%$ of DDGS in poultry feed mixture decrease its utilization, while Wang et al. (2007) proved that DDGS of good quality can be used in broiler diets at $15-20 \%$, with little adverse effect on live performance, but might result in some losses of dressing percentage or breast meat yield. Therefore, many authors stress that correct DDGS utilization in poultry feed mixture requires precisely designation of its inclusion for particular species and technological groups (Roberson et al. 2005, Wang et al. 2007).

Although in Poland, as in other European countries, the duck meat production is not as high as chicken or turkey, in the last decades the increasing interest in alternative meat consumption can be observed. Duck meat is rich in unsaturated fatty acids (Batura et al. 1990, Bernacki \& Adamski 2001) what makes it very tasty, of a high nutritive value and therefore worth popularisation.

Ducks are very sensitive to any nutrient deficiency, incorrect feed formulation or feed contamination with different unwholesome substances, That's why they are recognized as good »bio indicator of feed quality. Moreover, talking about effective production of poultry meat, the relative costs of feeds play a very important role since they constitute from 70 to $75 \%$ of producer expenses (Amerah et al. 2007).

Sex differences in body size of Pekin duck (Anas platyrhynchos L.) aren't as evident as in Muscovy (Cairina moschata L.) (Sauveur 1990), therefore both sexes are usually reared together and the sex effect on slaughter yield or meat quality have received little attention. However, in chicken broilers also reared commercially without sexing, there are some evidences about sex influence on meat characteristics and its sensory value (Horsted et al. 2005).

Taking above into consideration the present study was designed to investigate the effect of DDGS inclusion level and duck sex on growth rate, slaughter yield, carcass composition and physical-chemical meat characteristics of Pekin ducks at the age of 8 weeks.

\section{Materials and methods}

The experiment was carried out on 160 commercial Pekin ducks (Anas platyrhynchos $\mathrm{f}$. domestica, strain P55). At the day of hatching birds were sexed, marked individually, weighed 
and divided randomly into four equal groups (four sup-groups, each). From Day 1 to Day 21 all birds were fed on the same commercial feed, while from 4th to 8th week of rearing the ducks were kept in four feeding groups: control - fed with the basic feed, and experimental groups fed on diets contained $15 \%, 25 \%$ or $30 \%$ DDGS. Additionally, from 3rd week of age until the end of the rearing period the mineral mixture with chalk and grit was provided.

The chemical composition of used DDGS, delivered by fuel ethanol plant in Murowana Goślina, Poland, was as follows: dry matter $93.06 \%$, crude protein $27.33 \%$, crude ash $5.67 \%$, crude fibre $7.25 \%$, fat $11.74 \%$, amino acid (in $\mathrm{g} / 100 \mathrm{~g}$ protein): lysine 2.49 , methionine + cystine 2.98 , threonine 3.95 , tryptophan 3.64 . The chemical composition and nutritive value of feed mixtures used for duck feeding shows Table 1.

During the entire rearing period the ducklings were housed on deep litter, under controlled environmental condition; feeds and water were available ad libitum. All birds were weighed individually at Day 1st, 3rd, 7th and 8th week, in order to calculate the growth rate (tw \%) for particular evaluated periods, according to following equation:

$$
t_{w} \%=\frac{(W 2-W 1)}{1 / 2(W 1+W 2)} \times 100 \% *
$$

where $W 1$ is the body weight at the beginning of evaluated period, $W 2$ is the body weight at the end of evaluated period; * (according to Świerczewska 1983).

Table 1

Chemical composition of the basic (control) and the experimental feeds for commercial Pekin ducks strain P551)

\begin{tabular}{|c|c|c|c|c|c|}
\hline \multirow[t]{2}{*}{ Contents } & \multirow{2}{*}{$\begin{array}{c}\text { Basic feed } \\
1-21 \text { day of rearing }\end{array}$} & \multicolumn{4}{|c|}{ Feeding groups from 4 to 8 week of rearing } \\
\hline & & Control & $15 \%$ DDGS & $25 \% \mathrm{DDGS}$ & $30 \% \mathrm{DDGS}$ \\
\hline MEN, MJ/kg & 11.8 & 12.2 & 12.3 & 12.3 & 12.3 \\
\hline Crude protein, \% & 20.0 & 17.4 & 17.8 & 18.0 & 17.7 \\
\hline Crude fibre, $\%$ & 3.0 & 3.1 & 3.5 & 3.8 & 3.9 \\
\hline Lysine, $\%$ & 1.0 & 0.9 & 0.9 & 0.9 & 0.9 \\
\hline Methionine+Cystine, \% & 0.8 & 0.7 & 0.7 & 0.7 & 0.7 \\
\hline Relative costs of $1 \mathrm{~T}$ feed, $\%$ & - & 100.0 & 86.16 & 77.95 & 72.05 \\
\hline
\end{tabular}

${ }^{1)}$ Feeds were standardized according to recommendations for commercial ducks (Smulkikowska \& Rutkowski 2005).

At the day of slaughter from each group the 5 males and 5 females of body weight closest to the average value for group and sex were selected, slaughtered in waterfowl slaughter house, and after $24 \mathrm{~h}$ of cooling at $4{ }^{\circ} \mathrm{C}$, the carcasses were collected for further analysis. The following parameters were evaluated (in grams, with $0.1 \mathrm{~g}$ accuracy, and in \%, in relation to live body weight and to eviscerated carcass with neck): eviscerated carcass with neck, neck without skin, wings with skin, breast and leg muscles, edible giblets (heart, liver, gizzard), skin with subcutaneous fat, abdominal fat and carcass residues (according to Ziołecki \& Doruchowski 1989). The $\mathrm{pH}$ was measured in left breast muscles $15 \mathrm{~min}\left(\mathrm{pH}_{15 \min }\right)$ post mortem and after 24 hours $\left(\mathrm{pH}_{24 \mathrm{~h}}\right)$ of cooling at $4^{\circ} \mathrm{C}$, using spear tip electrode combined with $\mathrm{pH}$-meter (CP-401, ELMETRON). The electrode was placed at an angle of $45^{\circ}$, halfway through the muscle. Meat colour measures (values: $L^{*}, a^{*}, b^{*}$ ) were made after $24 \mathrm{~h}$ of cooling using Minolta CR-400/410 apparatus. Meat water contents (according Grau \& Hamm 1952) and chemical analysis (AOAC 1995) were performed in minced and homogenized right breast muscles. 
The data obtained were analysed using software Statistica version 7.1 (StatSoft 2005) and were verified statistically with ANOVA, while the significance of differences by Duncan's multiple range test.

\section{Results}

The average body weights of one-day old male (52.7-54.9 g) and female (52.6-53.9 g) ducklings were similar, however after three weeks of rearing, despite receiving the same diet, the females from the control group $(976.3 \mathrm{~g})$ had lower $(P<0.05)$ body weight than in the $15 \%$ DDGS group $(1163.9 \mathrm{~g})$. At 7th week of age no significant effect of dietary treatments was observed and only females from $30 \%$ DDGS group $(2830.5 \mathrm{~g})$ were significantly $(P<0.05)$ lighter than males $(3027.5 \mathrm{~g})$. At the day of slaughter the only sex effect was stated in $30 \%$ DDGS group and females from this treatment were characterized by the lowest body weight $(2960.0 \mathrm{~g})$. It was significantly $(P<0.05)$ lower comparing to the control and $25 \%$ DDGS group (Table 2 ).

The growth rate of male and female ducks, depending on DDGS inclusion level is presented on Figures 1 and 2. As it could be expected, the highest growth rates occurred during the first three weeks and in general, were faster in females than males, however significant $(P<0.05)$ differences were stated only in $15 \%$ DDGS group - $182.5 \%$ in females (Figure 2) and $179.9 \%$ in males (Figure 1). In $15 \%$ DDGS female group the average growth rate was also significantly $(P<0.05)$ higher, comparing to the control and $30 \%$ DDGS group.

Within next period (3-7 week) growth rates decreased almost twice (to 89.0-104.5\%) and in the control groups of both sex were higher $(P<0.05)$ than in the experimental groups. As previously, sex effect was observed only in $15 \%$ DDGS group, but males (99.2\%) had higher rate as females (89.0\%). During the last week of rearing the further decrease in growth rate could be noted, and significant $(P<0.05)$ differences caused by diet were observed between the control and $30 \%$ DDGS group (Figure 2) and sex differences in 30\% DDGS group (6.9\% males vs. $10.7 \%$ females).

The females of $25 \%$ DDGS group were characterized by the highest average weight of carcass with neck, and it was higher $(P<0.05)$ than in $30 \%$ DDGS group. In every group the slaughter yield of females was higher than males, however significant $(P<0.05)$ differences were noted for the control and $15 \%$ DDGS group.

It is very promising that DDGS, despite inclusion level and bird sex (excluding the control group for legs muscles) did not affect the muscles contents (Table 2).

The females of $30 \%$ DDGS group were characterized by the lowest contents $(P<0.05)$ of skin with subcutaneous fat and abdominal fat. Except this group, both mentioned traits had higher values in female carcass when comparing with males, but significant sex differences were referred only to skin with subcutaneous fat contents (Table 2). 




${ }^{1)}$ Average values within evaluated period with different superscripts differ significantly, ${ }^{a, b} p<0.05$

Figure 1

The growth rate of Pekin male ducks up to 8 th week of age ( $n=40$; means $\pm S D)$

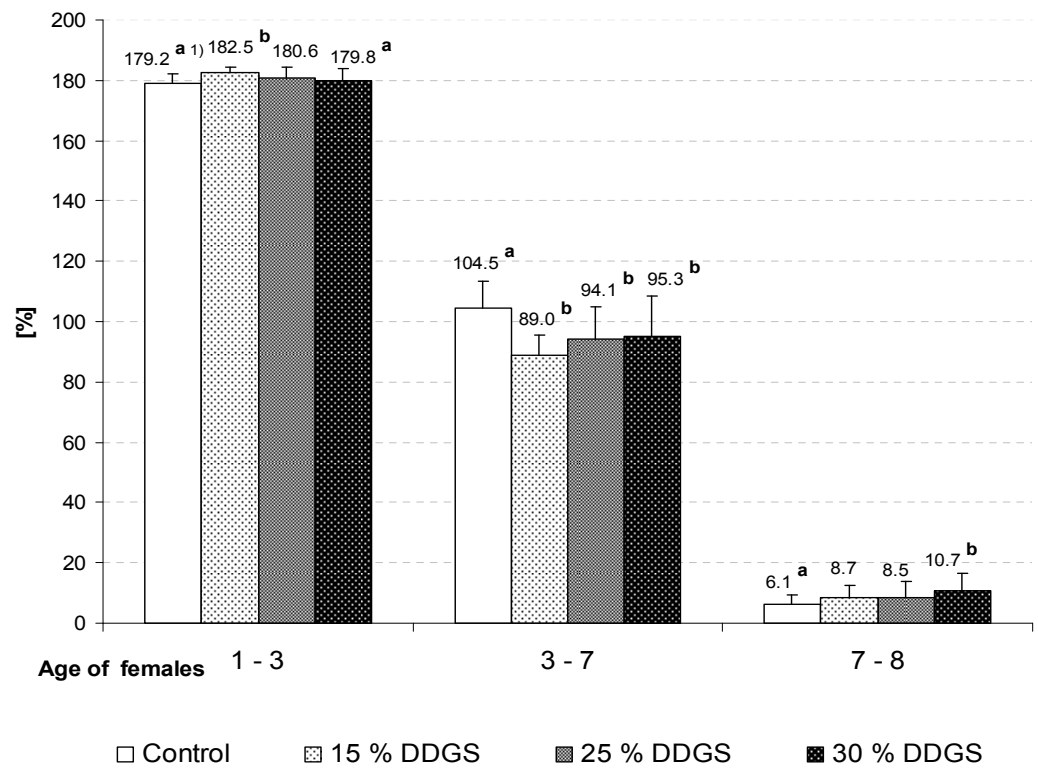

${ }^{1)}$ Average values within evaluated period with different superscripts differ significantly, ${ }^{a, b} P<0.05$

Figure 2

The growth rate of Pekin female ducks up to 8 th week of age $(n=40$; means $\pm S D)$ 


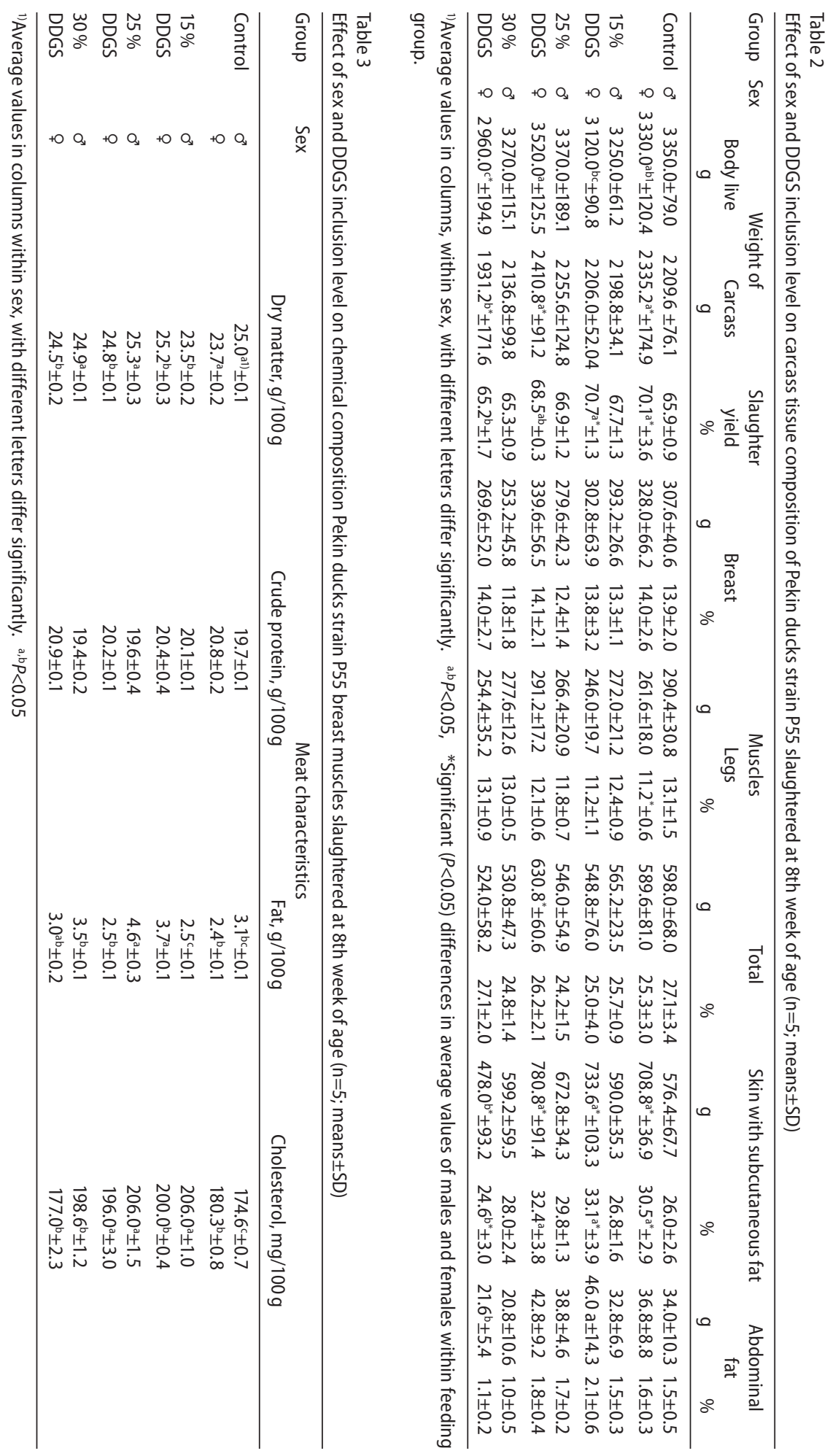


The amount of other evaluated carcass elements varied between groups and sex, however existing differences were not significant. The weight of neck without skin varied from 154.4 to $182.8 \mathrm{~g}$, wings with skin $-236.0-282.8 \mathrm{~g}$, edible giblets $132.8-180.4 \mathrm{~g}$ and remainder of carcass from 486.8 to $575.6 \mathrm{~g}$. Sex differences $(P<0.05)$, in relation to all mentioned traits, were observed in $15 \%$ DDGS group.

Despite DDGS level, there was any significant sex effect on chemical characteristics of breast meat. Also crude protein content was not affected by treatment (Table 3). DDGS inclusion increased $(P<0.05)$ the dry matter content in female breast muscles. The fat and cholesterol content varied depending both, on sex and DDGS level. Fat level $(P<0.05)$ was particularly high in $250 \%$ DDGS male meat, while cholesterol contents in $15 \%$ and $25 \%$ DDGS male group (Table 3).

DDGS inclusion level and ducks sex had any significant effect on the physical characteristics, i.e. $\mathrm{pH}_{15 \mathrm{~min}^{\prime}} \mathrm{pH}_{24 \mathrm{~h}^{\prime}}$ meat colour $\left(\mathrm{L}^{*}, \mathrm{a}^{*}, \mathrm{~b}^{*}\right)$ and water contents of breast muscles. The $\mathrm{pH}_{15 \mathrm{~min}}$ and $\mathrm{pH}_{24 \mathrm{~h}}$ varied from 6.0 to 6.4; the meat lightness ( $\mathrm{L}^{*}$ value) - from 40.7 (male control group) to 42.7 (female $25 \%$ DDGS); redness (a*) - from 17.2 (female 15\% DDGS) to 19.0 (female 30\% DDGS) and yellowness ( $\left.b^{*}\right)$ from 2.4 in male control and $15 \%$ DDGS group) to 3.6 in $30 \%$ DDGS female group. The water content varied from 74.6 to $79.6 \%$.

\section{Discussion}

It is consider that among all poultry species ducks are characterized by one of the highest initial (up to 3 weeks of age) growth rate (Ricklefs 1985), what was confirmed in the present experiment. Moreover, during this period body weight gains in females were faster than in males, however in the subsequent weeks of rearing such differences were not observed. Our results did not confirm the significant differences in growth rate and final body weight caused by bird sex that were described by Bochno et al. (2005).

The DDGS inclusion up to $25 \%$ did not affect the final body weights of 8 weeks old ducks, and results obtained (3250-3 370 g in males and $3120-3520 \mathrm{~g}$ in females) were higher than in the different Pekin hybrids examined by Bernacki et al. (2006) (from 2825 to $3323 \mathrm{~g}$ ) and comparable to pekin A44 strain ( $3540 \mathrm{~g}$ males and $3229 \mathrm{~g}$ females), examined by Witak (2008). The sex effect was observed only in $30 \%$ DDGS group. Significant differences in body weight between males and females were described by Witkiewicz et al. (2006) and Witak (2008), but Książkiewicz (2002), working on conservative Pekin strain P33 and Mazanowski et al. (2003) evaluating parental strains A44 and A55 did not found sex differences.

Although DDGS inclusion in $30 \%$ decreased $P<0.05)$ the slaughter yield, results obtained in the other groups were similar comparing to $68.81-70.04 \%$ indicated by Bernacki et al. (2006) and higher than in A44 strain (65.5\% in males and $66.8 \%$ in females) indicated by Witak (2008). The later author stated also significant sex differences, while in the presented study they were observed only in the control and $15 \%$ DDGS group (females were heavier).

It is very important, from consumers and technological view point, that the weight and percentage of the breast and leg muscles were affected neither by DDGS level nor by sex, and were comparable to data of Bernacki et al. 2006, but lower when compared with $16.9 \%$ in males and $15.5 \%$ in females breast muscle contents and $13.4 \%$ and $14.8 \%$ of leg muscles, respectively in A44 strain (Witak 2008). 
Pekin duck carcass is considered by consumers as unattractive and rich in calories, mostly due to high contents of skin with subcutaneous fat. In 8 weeks old ducks analysed in our experiment, the lowest contents of skin with subcutaneous fat $478 \mathrm{~g}$ in females and $599 \mathrm{~g}$ in males; $24.6 \%$ and $28.0 \%$, respectively in relation to carcass weight) was observed in $30 \%$ DDGS group, and these values were significantly $(P<0.05)$ lower when compared with other dietary groups. Also in the remained groups the contents of skin with subcutaneous fat was lower than in A44 strain evaluated by Bochno et al. (2005) (759.6g) and comparable to 30.6-31.3\% described by Witak (2008). Abdominal fat contents was affected neither by neither by sex nor by DDGS level, varying from $20.8 \mathrm{~g}$ (in males of $30 \%$ DDGS) to $46.0 \mathrm{~g}$ (females of $15 \%$ DDGS group). Wawro et al. (2004) comparing the meat quality of Pekin and Muscovy ducks indicated that Muscovy males slaughtered at 12th week of age (with $4451 \mathrm{~g}$ of final body weight) had $84.5 \mathrm{~g}$ of abdominal fat), while Pekin males reared to 7th week (at body weight $3008 \mathrm{~g}$ ) only $34.5 \mathrm{~g}$.

Physical traits (water contents, $\mathrm{pH}$ and meat colour) and chemical composition of meat are crucial, regarding the technological properties and sensory quality of duck meat, while meat colour, which is closely related with meat pH (Strzyżewski et al. 2008), genotype and relative proportion of myoglobin forms (Mancini \& Hunt 2005; Wołoszyn et al. 2009), contributes significantly to consumer choice and acceptance. In our experiment the above mentioned traits were not affected both, by duck sex and dietary treatments, that is consistent with results of Corzo et al. (2009) in relation to broiler chickens fed $8 \%$ DDGS. The lightness of meat colour $\left(\mathrm{L}^{*}\right)$ (40.7-42.3) was higher than in Turkish Pekin evaluated by Lacin et al. (2008) (33.06), but similar as of other Polish strains and breeds (Wołoszyn et al. 2009). Our results did not confirmed the findings of Chartrin et al. (2006) that muscles containing high lipid level are paler and have greater intensity of yellowness, because muscles of the highest fat content were not characterised by the highest lightness or lowered redness. The $\mathrm{pH}_{15 \text { min }}$ values (6.16.4) were similar to 6.19 stated by Witak (2008) and 5.9-6.2, by Bernacki et al. (2006).

Similar as the physical traits, the crude protein contents in evaluated duck meat was affected nether by DDGS level nor by sex dimorphism, however the dry matter, fat and cholesterol content differed, depending on DDGS level, but not on sex. Witak (2008) described lower and sex dependent crude protein level in breast muscles of 8 weeks old Pekin A44 strain (19.8\% in males and $19.4 \%$ in female). In experiment carried on parental strains A44 and A55 the water contents (opposite to dry matter) in breast muscles varied from 71.4 to $77.3 \%$ (Mazanowski et al. 2003) and in Pekin hybrids from 73.3 to $74.4 \%$ (Bernacki et al. 2006), what is similar to our results, while fat contents from 1.6 to $1.8 \%$ and from 2.3 to $2.7 \%$, respectively and these values were lower comparing to the results obtained in presented experiment (4.6-2.4 g/100 g), however any simply relations between sex and DDGS level, in relation to fat and cholesterol contents (174.6-206.0 mg/100 g) were observed.

The results of our experiment showed that Pekin ducks can be fed on diets containing up to $25 \%$ DDGS without any significant decrease in slaughter yield, muscles contents and breast meat quality. Moreover, from economic point of view, it is very important, that with an increase in DDGS level the relative costs of 1 ton feed decrease. When $25 \%$ DDGS was included, the relative cost of 1 ton of feed constituted only $78 \%$ of the basic feed. The DDGS inclusion of $30 \%$ caused significant $(P<0.05)$ decrease in final body weight and slaughter yield of females, however, the percentage of skin with subcutaneous fat and abdominal fat contents were lower $(P<0.05)$. 


\section{Acknowledgements}

The presented experiment was conducted with the permission of II Local Ethics Commission for Experiments Carried on Animals and was financially supported by the Ministry of Science and High Education of Poland. Project No. R12 05903.

\section{References}

Amerah AM, Ravindran V, Lentle RG, Thomas DG (2007) Feed particle size: Implications on the digestion and performance of poultry. Worlds Poult Sci J 63, 439-455

AOAC (1995) Official Methods of Analysis of AOAC International. Association of Analytical Communities, 2 volumes, 16th edition, Arlington, VA, USA

Batura J, Korzeniowski W, Bochno, R (1990) Effect of restricted feeding of ducks on fatty acids composition in reserve and muscle fat. Przeg Nauk Lit Zoot 35, 133-140

Bernacki Z, Adamski M (2001) Evaluation of growth, slaughter values and fatty acids content in breast muscles of two breeding lines of ducks. Zesz Nauk Przeg Hod 57, 455-465 [in Polish]

Bernacki Z, Adamski M, Kuźniacka J, Kokoszyński D (2006) Comparison of meat traits in ducks of different origin to 9 weeks of age. Rocz Nauk Zoot 33, 41-57 [in Polish]

Bochno R, Brzozowski W, Murawska D (2005) Age-related changes in the distribution of lean, fat with skin and bones in duck carcases. Br Poult Sci 46, 199-203

Chartrin P, Bernadet MD, Guy G, Mourot J, Duclos MJ, Baeza E (2006) Effect of genotype and overfeeding on fat level and composition of adipose and muscle tissue in ducks. Anim Res 55, 231-244

Corzo A, Schilling MW, Loar RE, Jackson V, Kin S, Radhakrishnan V (2009) The effects of feeding distillers dried grains with solubles on broiler meat quality. Poult Sci 88, 432-439

Grau R, Hamm R (1952) A simple method for the measuring of water binding capacity in meat. Fleischwirtschaft 4, 295-297 [in German]

Horsted K, Henning J, Hermansen JE (2005) Growth and sensory characteristics of organically reared broilers differing in strain, sex and age at slaughter. Acta Agric Scand A 55, 149-157

Książkiewicz J (2002) Reproductive and meat characteristics of Polish ducks threatened with extinction. Czech J Anim Sci 47, 401-410

Lacin E, Aksu Ml, Macit M, Yildiz A, Karaoglu M, Esenbuga N, Yoruk MA (2008) Effects of different raising systems on colour and quality characteristics of Turkish Pekin duck meats. S Afr J Anim Sci 38, 217-223

Lumpkins BS, Batal AB, Dale NM (2004) Evaluation of distillers dried grains with solubles as a feed ingredient for broilers. Poult Sci 83, 1891-1896

Lumpkins BS, Batal AB, Dale NM (2005) Use of Distillers Dried Grains Plus Solubles in Laying Hen Diets. J Appl Poult Res 14, 25-31

Mancini RA, Hunt MC (2005) Current research in meat color. Meat Sci 71, 100-121

Mazanowski A, Kisiel T, Gornowicz E (2003) Carcass quality, meat traits and chemical composition of meat in ducks of paternal strains A44 and A55. Anim Sci Pap Rep 21, 251-263

Ricklefs RE (1985) Modification of growth and development of muscles of poultry. Poult Sci 64, 1563-1576

Roberson KD (2003) Use of dried distillers' grains with solubles in growing-finishing diets of turkey hens. Int J Poult Sci 2, 389-393

Roberson KD, Kalbfleisch JL, Pan W, Charbeneau RA (2005) Effect of Corn Distiller's Dried Grains with Solubles at Various Levels on Performance of Laying Hens and Egg Yolk Color. Int J Poult Sci 4, 44-51

Sauveur B (1990) Origines et performances comparées du canard de Barbarie et du canard commun de race Pékin. In: Sauveur B, de Carville H (eds.) Le Canard de Barbarie, INRA, Paris, France, 3-11 [in French]

Smulikowska S, Rutkowski A (2005) Feeding recommendations and nutritive values of feed. Normy Żywienia Drobiu, IPAN, PAN, Jabłonna, Poland, 3-136 [in Polish] 
StatSoft (2005) Statistica version 7.1, StatSoft Inc, Tulsa, OK, USA

Strzyżewski T, Bilska A, Krysztofiak K (2008) Correlation between pH value of meat and its color. Nauk Przyr Techn 2, 1-9 [in Polish]

Świątkiewicz S, Koreleski J (2003) An attempt to use dried corn distillers grains as a component of diets for broiler chickens. Rocz Nauk Zoot 30, 367-379 [in Polish]

Świątkiewicz S, Koreleski J (2006) Effect of maize distillers dried grains with solubles and dietary enzyme supplementation on the performance of laying hens. J Anim Feed Sci 15, 253-260

Świątkiewicz S, Koreleski J (2008) The use of distillers grains with solubles (DDGS) in poultry nutrition. Worlds Poult Sci J 64, 257-265

Świerczewska E (1983) Utilization of meat-type chicken. In: Potemkowska E. (ed.) Technology of Industrial Poultry Production. PWRiL, Warsaw, Poland, 369-374 [in Polish]

Wang Z, Cerrate S, Coto C, Yan F, Waldroup PW (2007) Utilization of distillers dried grains with solubles (DDGS) in broiler diets using a standardized nutrient matrix. Int J Poult Sci 6, 470-477

Wawro K, Wilkiewicz-Wawro E, Kleczek K, Brzozowski W (2004) Slaughter value and meat quality of Muscovy ducks, Pekin ducks and their crossbreeds, and evaluation of the heterosis effect. Arch Tierz 47, 287-299

Witak B (2008) Tissue composition of carcass, meat quality and fatty acid content of ducks of a commercial breeding line at different age. Arch Tierz 51, 266-275

Witkiewicz K, Kontecka H, Książkiewicz J (2006) Basic elements of eviscerated carcass and chemical composition of pectoral muscle in selected and unselected ducks (short communication). Arch Tierz 49, 502-507

Wołoszyn J, Haraf G, Książkiewicz J, Okruszek A (2009) Influence of genotype on duck meat color. Med Weter 65, 836-839

Wołoszyn J, Książkiewicz J, Skrabka-Błotnicka T, Haraf G, Biernat J, Kisiel T (2006) Comparison of amino acid and fatty acid composition of duck breast muscles from five flocks. Arch Tierz 49, 194-204

Ziołecki J, Doruchowski W (1989) Method of slaughter value evaluation in poultry. COBRD, Poznań, Poland, $1-32$ [in Polish]

Received 14 February 2011, accepted 28 March 2011.

Corresponding author:

Ewa Łukaszewicz

email: ewa.lukaszewicz@up.wroc.pl

Wrocław University of Environmental and Life Sciences, Institute of Animal Breeding, Division of Poultry Breeding, Institute of Animal Breeding, Wrocław University of Environmental and Life Sciences, Chełmońskiego 38a, 51-630 Wrocław, Poland 